\title{
OBRIGATORIEDADE DE OBSERVÂNCIA DO PRINCÍPIO DO JULGADOR NATURAL NA SINDICÂNCIA E NO PROCESSO ADMINISTRATIVO DISCIPLINAR: EFETIVAÇÃO DO DIREITO E GARANTIA FUNDAMENTAL COMO FORMA DE ACESSO À JUSTIÇA
}

\section{OBLIGATION TO OBSERVE THE PRINCIPLE OF THE NATURAL JUDGER IN THE TRADE UNION AND IN THE DISCIPLINARY ADMINISTRATIVE PROCESS: EFFECTIVENESS OF FUNDAMENTAL LAW AND GUARANTEE AS A FORM OF ACCESS TO JUSTICE}

JUAN FERNANDO DURÁN ALBA

Doctor en Derecho por la Universidad de Valladolid. Profesor Titular de Derecho Constitucional en la Facultad de Derecho de Valladolid. Abogado. Subdirector de la Revista General de Derecho Constitucional, editada por lustelPortal de Derecho, y miembro de su Consejo Editorial (desde 2016). Secretario de la Facultad de Derecho de Valladolid (2004-2008). Letrado de adscripción temporal en el Tribunal Constitucional (2008-2014). Vocal de la Junta Electoral de Castilla y León (20072008).

\section{IVAN APARECIDO RUIZ}

Pós-doutor pela Faculdade de Direito da Universidade de Lisboa - FDUL (2013). Doutorado em Direito pela Pontifícia Universidade Católica de São Paulo - PUC/SP (2003). Mestrado em Direito Negocial pela Universidade Estadual de Londrina UEL/PR (1996) e Professor pesquisador visitante na Università degli Studi di Camerino (UNICAM), Itália. Atualmente, é professor associado da Universidade Estadual de Maringá (UEM/PR). E-mail: ivanaparecidoruiz@gmail.com. http://lattes.cnpq.br/8393076707737696. 


\section{HORÁCIO MONTESCHIO}

Pós doutorando pela Universidade de Coimbra. Doutor em Direito pela FADISP. Mestre em Direitos da Personalidade - UNICESUMAR. Professor de Direito Administrativo e Processo Administrativo do UNICURITIBA. Especialista em Direito Imobiliário e Direito Processual Civil pela EPD; Processo Civil e Direito Público, pelo Instituto Brasileiro de Estudos Jurídicos; Direito Tributário, pela UFSC; Direito Administrativo, pelo IRFB; Direito Aplicado pela Escola da Magistratura do Estado do Paraná. h.monteschio@uol.com.br http://lattes.cnpq.br/8861821320530256.

GUSTAVO KFOURI

Investigador, membro dos grupos de pesquisa Cidadania Empresarial no Século XXI Unicuritiba - Brasil, e integrante do grupo de Pesquisa Internacional - REDTH(Rede de Estudos em Direitos Huamanos e Transnacionalidade).

\section{RESUMO}

Objetivo: $O$ presente artigo tem por objetivo fazer uma reflexão sobre a obrigatoriedade de observância do princípio do julgador natural também na sindicância e no processo administrativo disciplinar, como forma de efetivar o direito e garantia fundamental na consecução do acesso à Justiça.

Metodologia: A proteção aos direitos fundamentais exerce forte influência na elaboração dos textos legislativos, não ficando restrita à sua abrangência as práticas do Poder Executivo. Desta forma, a proteção dos direitos fundamentais e sua aplicação imediata representa um dos baluartes do Estado Democrático de Direito, para tanto, as reflexões serão pautadas na legislação, doutrina e decisão dos tribunais do Brasil.

Resultados: Conclui-se que não deve haver comissões temporárias ad hoc constituídas após os fatos faltos, devendo haver comissões permanentes constituídas na Administração Pública. As comissões temporárias ad hoc normalmente são verdadeiras "comissões de encomenda", prejudicando os direitos e garantias fundamentais e também os princípios da Administração Pública; ou seja, o princípio da legalidade, o princípio da moralidade, o princípio da eficiência e o princípio da impessoalidade além de outros princípios, como o princípio do devido processual legal e o princípio da segurança jurídica. Sem a observância desses princípios, não se pode tratar sobre o acesso à justiça de forma plena, útil e eficiente em que haja Justiça nas decisões.

Contribuições: $O$ entendimento claro sobre a inexistência do juízo ou tribunal de 
exceção no Brasil, bem como a possibilidade de aplicação do princípio do juiz natural na sindicância e no processo administrativo disciplinar. A Constituição da República Federativa do Brasil de 1988, no seu art. $5^{\circ}$., inc. XXXVII, afirma que não haverá juízo ou tribunal de exceção. Em virtude desta norma, a contrario sensu, decorre o princípio do juiz natural. Muitos estudiosos do Direito entendem que essa 
norma só se aplica ao processo judicial. No entanto, defende-se, no presente texto, que o referido princípio coexiste no processo administrativo e deve ser observado obrigatoriamente na sindicância e no processo administrativo disciplinar, devendo a comissão que desenvolverá toda atividade processual, principalmente a fase de instrução, ser constituída antes da ocorrência dos fatos apontados como infrações disciplinares e sujeitas à sanção administrativa.

Palavras-chave: princípio do juiz natural; sindicância e processo administrativo disciplinar; comissão nomeada previamente; nulidade processual; violação de direito e garantia fundamental.

\section{ABSTRACT}

Objective: To reflect on the mandatory observance of the principle of the natural judge also in the investigation and in the disciplinary administrative process as a way of making the right and fundamental guarantee in achieving access to Justice.

Methodology: The protection of fundamental rights has a strong influence on the drafting of legislative texts and the practices of the Executive Power are not restricted to its scope. The protection of fundamental rights and their immediate application represents one of the fundamentals of the Democratic State of Law, therefore the reflections will be guided by the legislation, doctrine and decision of the courts of Brazil.

Results: There should be no temporary ad hoc commissions constituted after the fault facts; there must be permanent commissions constituted in the Public Administration. Temporary ad hoc commissions are usually true "commission orders", undermining fundamental rights and guarantees and also the principles of Public Administration; that is, the principle of legality, the principle of morality, the principle of efficiency and the principle of impersonality in addition to other principles, such as the principle of due process of law and the principle of legal certainty. Without the observance of these principles it is not possible to deal with access to Justice in a full, useful and efficient way in which there is justice in decisions.

Contributions: A clear understanding of the absence of an exception court or tribunal in Brazil, as well as the possibility of applying the principle of the natural judge in the investigation and in the disciplinary administrative process. The Constitution of the Federative Republic of Brazil of 1988 in its article 5, paragraph XXXVII, states that there will be no exception court or tribunal. By virtue of this rule, in contrario sensu, the principle of the natural judge arises. Many law scholars understand that this rule only applies to judicial proceedings. However, it is defended in this paper that such principle co-exists in the disciplinary administrative process; the commission that will develop all procedural activity, mainly the investigation 
phase, will be constituted before the occurrence of the facts identified as disciplinary infractions and subject to administrative sanction.

Keywords: principle of the natural judge; investigation and disciplinary administrative proceedings; previously appointed commission; procedural nullity; violation of rights and fundamental guarantee.

\section{INTRODUÇÃO}

Este texto tem por objetivo fazer uma reflexão sobre a obrigatoriedade de observância do princípio do julgador natural também na sindicância e no processo administrativo disciplinar, como forma de efetivar o Direito e a garantia fundamental, na consecução do acesso à justiça.

É também objetivo deste texto fomentar a discussão entre os estudiosos e pesquisadores do Direito.

Tem-se observado nos processos administrativos, de um modo geral, nas mais diversas esferas de Governo e órgãos públicos, que a higidez do Direito e garantia fundamental do juiz (julgador) natural encontra-se ameaçado em face da presença de comissões de sindicância e de processos administrativos constituídos por meio de nomeação de seus integrantes, ex post facto, como ocorre em tribunais de exceção, sabidamente vedado no Brasil.

Mesmo em faced o direito e da garantia fundamental do juiz natural, insculpida no art. $5^{\circ}$., inc. XXXVII, da Constituição da República Federativa do Brasil de 1988 (CRF/1988), no sentido de garantir-se aos brasileiros e estrangeiros residentes no País que não haverá juízo ou tribunal de exceção, o intérprete é levado a pensar que aludida garantia deva ser observada somente no processo judicial. No entanto, surge a importante questão de refletir-se se a referida garantia não é de ser observada também no processo administrativo, quer seja de sindicância ou de processo administrativo disciplinar propriamente dito.

Neste contexto, o processo administrativo, também deverá estar presente a inseparável imparcialidade que deve nortear todo julgador, quando do exercício de suas funções, seja para a existência e para a validade dos atos de todo e qualquer 
processo. Não se pode admitir, mormente num Estado Democrático de Direito, as chamadas "comissões de encomenda", quer para beneficiar ou prejudicar aquele que pratica uma infração disciplinar perante a Administração Pública, absolvendo ou aplicando uma sanção disciplinar.

Para tanto e diante disto, surge, antes, pois, a necessidade de fazer-se uma breve incursão ao conceito de jurisdição e, também, sobre o princípio da imparcialidade, para, se for o caso, concluir pela obrigatoriedade ou não do princípio do julgador natural no processo administrativo.

Dessa forma, as reflexões serão pautadas na legislação, doutrina e decisão de nossos tribunais.

A temática merece ser pesquisada, estudada, não só pela sua relevância no âmbito da Administração Pública, porquanto faz parte de seu cotidiano, mas, sobretudo, para observância dos Princípios da legalidade, da impessoalidade, moralidade e eficiência, princípios que toda a Administração Pública deverá obedecer, além de outros princípios, dentre eles, v. g., do devido processo legal, segurança jurídica, tudo pela plena concretização do Estado Democrático de Direito. Justifica-se, dessa forma, a presente pesquisa e estudo. ${ }^{1}$

\section{DA JURISDIÇÃO E DA IMPARCIALIDADE DO JULGADOR}

\subsection{DA JURISDIÇÃO}

Dentre as funções do Estado, cabe a cada um dos Poderes a atuação em uma delas. Assim, ao Poder Legislativo cabe legislar, ao Poder Executivo

\footnotetext{
${ }^{1}$ Esse entendimento, de observação desses princípios, encontra-se apoio nas decisões do Superior Tribunal de Justiça (STJ), conforme se vê de parte da ementa constante na decisão: "A aplicação do princípio do juiz natural mostra-se viável em sede de processo administrativo, como corolário dos princípios da segurança jurídica, do devido processo legal e da ampla defesa. Sem embargo dessa orientação, verifica-se que na hipótese não houve ofensa ao princípio destacado". [RMS 24258/RN Recurso Ordinário em Mandado de Segurança 2007/0122402-7, relatora Ministra Denise Arruda, órgão julgador T1 - Primeira Turma, data do julgamento 13/11/2007, data da publicação/fonte DJ $12 / 12 / 2007$ p. 388, v. u.].
} 
administrar, e ao Poder Judiciário o exercício da jurisdição estatal, realizando o Direito.

O conceito de jurisdição não é um conceito pronto e acabado. Muitas são as cizânias que podem surgir sobre o mesmo, a começar, por exemplo, pelos conceitos de jurisdição contenciosa e jurisdição voluntária. Neste caso, já se tem a primeira dificuldade em estabelecer-se um conceito uniforme e universal para a jurisdição.

No que concerne à jurisdição, Paulo Roberto de Gouvêa Medina, assim se pronuncia:

\begin{abstract}
Jurisdição é a função de julgar ou de emitir pronunciamentos judiciais, exercida por órgão independentes e imparciais que a lei indica, com o escopo de estabelecer a certeza em torno das pretensões deduzidas no processo, por meio da ação própria. Quando a jurisdição tem por escopo o julgamento de litígios ou lides, ela diz contenciosa. Quando, ao revés, o seu exercício se dá com a finalidade de constituir negócios jurídicos que, por envolverem, em geral, interesses indisponíveis, exigem a intervenção estatal para que adquiram validade, ela se diz jurisdição voluntária (MEDINA, 2018, p.45-46).
\end{abstract}

Ao estudar o conceito de jurisdição, salienta-se que a jurisdição pode ser analisada como poder, como função e como atividade. Como poder, é a manifestação do poder estatal, ou seja, capacidade de decidir imperativamente e impor decisões; como função, expressa o encargo que têm os órgãos jurisdicionais de promover a pacificação de conflitos de interesses interindividuais e coletivos, mediante a realização do Direito justo, utilizando-se para tanto, do processo; e como atividade ela é o complexo de atos no juiz no processo, exercendo, assim, o poder e cumprindo a função que lhes comete.

Também, dependendo do enfoque e das características (lide, inércia, definitividade, substitutividade, imparcialidade, etc.) que se trabalha e que se atribui à jurisdição, chega-se a conclusões totalmente diversas a respeito do conceito de jurisdição. Basta, por exemplo, pensar no caso de atrelar-se o conceito de lide à jurisdição, que se terá conclusões diversas no concernente à coisa julgada. Neste caso, só se poderia falar em jurisdição quando presente a lide, o que fatalmente leva à conclusão da existência da coisa julgada na jurisdição voluntária e sua ausência 
na jurisdição voluntária, graciosa ou administrativa (ARAÚJO CINTRA; et. al., 2018, p.30).

Outra das características que se tem apontado acerca da jurisdição é a imparcialidade do julgador. Neste contexto, encontra-se diante do princípio da imparcialidade, objeto do tópico seguinte.

\subsection{DA IMPARCIALIDADE DO JULGADOR}

Os autores de Teoria geral do Processo têm apontado a imparcialidade como uma das características da jurisdição, tanto que se tem afirmado, de forma correntia, que a imparcialidade é inseparável da jurisdição, ou seja, não há jurisdição sem que esteja presente a imparcialidade. Não é demais lembrar que a imparcialidade do juiz é um processo de validade para que a relação jurídica processual instaure-se e desenvolva-se. Um julgador parcial afeta substancialmente o seu poder, a sua função e a sua atividade. A presença de um juiz natural e imparcial é uma preciosa garantia de justiça para as partes em conflito de interesses. O tribunal de exceção, vedado pela nossa Constituição da República Federativa do Brasil de 1988, não convive com o juiz natural e imparcial. Este, ao revés, contrapõe-se àquele. Deve viger, portanto, o juiz natural e imparcial.

A garantia do juiz natural, como ensina Antonio Carlos de Araújo Cinta e outros (2018, p.70):

[...] desdobra-se em três conceitos: a) só são órgãos jurisdicionais os instituídos pela Constituição; b) ninguém pode ser julgado por órgão constituído após a ocorrência do fato; c) entre os juízes pré-constituídos vigora uma ordem imperativa de competências que exclui qualquer alternativa deferida à discricionariedade de quem quer que seja.

Diante desses desdobramentos, verifica-se, desde logo, a ilegalidade na criação de comissões de sindicância ou do Processo Administrativo disciplinar post facto, afetando o caso da letra "c" acima, e é o mais evidente, muito recorrente na Administração Pública. A escolha feita dos integrantes da comissão processante, de forma discricionária pelo administrador público, mostra-se excessivamente 
temerária, pois quem a nomeia pode pinçar servidores talhados a determinado desiderato previamente conhecido. Assim, essa postura do administrador público deve ser evitada.

O contrassenso é por demais evidente, em termos comparativos, v. g., com o processo licitatório, no qual se exige a presença de uma comissão permanente de licitação consoante a redação do art. 51 , $4^{\circ 2}$ da Lei federal №. 8.666/93. Com efeito, os processos administrativos de investigação devem assegurar a mesma garantia de constituição prévia, sob pena de subjugar as garantias constitucionais do administrado, evitando perseguições mesquinhas e, de outro lado, preservar higidez da permanência na Administração Pública de servidores que recebam a condescendência de seus colegas.

Seguindo esse entendimento são os meios jurídicos-processuais ofertados ao servidor público que se encontre em situação de sensível quadro de perseguição administrativa em face da composição da comissão de processo administrativo, constituídas pelos não recomendáveis motivos de suspeição e impedimento, presentes nos arts. $18^{3}, 19^{4}, 20^{5}$ e $21^{6}$ da Lei federal no. 9784/99. Registre-se que a Lei Federal ํo. 8.112/90, que dispõe sobre o Regime Jurídico dos Servidores Públicos Civis da União, das autarquias e das fundações públicas federais, em seu art. 149, foi omissa quanto à suspeição.

\footnotetext{
2 "Art. 51. A habilitação preliminar, a inscrição em registro cadastral, a sua alteração ou cancelamento, e as propostas serão processadas e julgadas por comissão permanente ou especial de, no mínimo, 3 (três) membros, sendo pelo menos 2 (dois) deles servidores qualificados pertencentes aos quadros permanentes dos órgãos da Administração responsáveis pela licitação. [...] $\S 4^{\circ} \mathrm{A}$ investidura dos membros das Comissões permanentes não excederá a 1 (um) ano, vedada a recondução da totalidade de seus membros para a mesma comissão no período subsequente". (original sem os itálicos).

3 "Art. 18. É impedido de atuar em processo administrativo o servidor ou autoridade que: I - tenha interesse direto ou indireto na matéria; II - tenha participado ou venha a participar como perito, testemunha ou representante, ou se tais situações ocorrem quanto ao cônjuge, companheiro ou parente e afins até o terceiro grau; III - esteja litigando judicial ou administrativamente com o interessado ou respectivo cônjuge ou companheiro".

4 "Art. 19. A autoridade ou servidor que incorrer em impedimento deve comunicar o fato a autoridade competente, abstendo-se de atuar. Parágrafo único. A omissão do dever de comunicar o impedimento constitui falta grave, para efeitos disciplinares".

5 "Art. 20. Pode ser arguida a suspeição de autoridade ou servidor que tenha amizade íntima ou inimizade notória com algum dos interessados ou com os respectivos cônjuges, companheiros, parentes e afins até o terceiro grau".

6 "Art. 21. O indeferimento de alegação de suspeição poderá ser objeto de recurso, sem efeito suspensivo".
} 
É texto legal, mas carente de correlação com a prática cotidiana pelo fato de que se apresenta totalmente insuficiente para a proteção do servidor que se encontra em situação de acusado frente a uma comissão, criada post facto, pois as perseguições, as diferenças pessoais e profissionais presentes no interior da Administração Pública não se circunscrevem às modestas previsões constantes na legislação de regência, a ponto de estabelecer uma real proteção e garantia aos direitos fundamentais daquele que está sendo, muitas vezes, indevidamente processado.

Saliente-se, que sob o ângulo da importância e da indisponibilidade do interesse público, a designação de comissão para apurar fatos violadores da higidez administrativa deve ser feita obedecendo, por exemplo, também nos moldes presentes na Lei de Licitações, para impedir eventuais perseguições ou mesmo excluir a possibilidade de prática tolerante ao faltoso. É uma garantia para ambos os lados, servidor e Administração Pública, até mesmo para que se observe e cumpra os princípios constitucionais de regência dos servidores públicos (art. 37, caput, da CRF/1988).

\section{ASPECTOS HISTÓRICOS E CONSTITUCIONAIS}

$\mathrm{Na}$ história do Direito, fazendo-se um corte histórico, inicia a análise das garantias presentes nos textos constitucionais relativos às garantias de proteção do administrado frente à Administração Pública. A Magna Carta, assinada por João Sem Terra, em 1215, trata-se de um documento assinado sob pressões dos barões, na Inglaterra, e no art. 39 garante: "39. Nenhum homem livre será capturado ou aprisionado, ou desapropriado dos seus bens, ou declarado fora da lei, ou exilado, ou de algum modo lesado, nem nós iremos contra ele, nem enviaremos ninguém contra ele, excepto pelo julgamento legítimo dos seus pares ou pela lei do país".

Mais tarde, em 1688, no mesmo sentido surge o Bill of Rights, quando em seu art. $3^{\circ}$. dispõe sobre a repugnância da criação de tribunais, órgãos julgadores 
criados post factum, quando estabelece: "The commission that instituted the former court of commissioners and courts of the same nature is illegal and noxious". ${ }^{7}$

Sob os auspícios da Revolução Francesa, a existência de um tribunal encarregado de julgar as questões controvertidas à sua análise foi expressamente consignada no texto constitucional de 1791 , nos seguintes termos "les citoyens ne peuvent être distraits des juges qui la loi leurs assigne par auxunes comissions ni par d'autres atribuitions et invocations qui celles qui sounts determinées par les lois". ${ }^{8}$

Ainda, no Direito francês, a exigência de um juiz encarregado de decidir os fatos ocorridos anteriormente, ou seja, o princípio do juiz natural restou reconhecido pelo texto constitucional daquele país no ano de 1814 , no qual "Nul ne pourra être distrait de ses juges naturels"9, princípio esse ratificado na Constituição de1830, o qual em seu art. 53 fulminou qualquer dúvida que ainda existia sobre a matéria, ao consignar que "Il ne pourra, em conséquence être créés des comissions e des tribuaux extraordinaires à quelquer titre e sous quelquer dénomination que se puísse être." 10

Desta posição não difere o Direito Italiano, por igual influenciado pelos efeitos nefastos ocorridos durante a Segunda Guerra Mundial, ao assegurar a proteção ao cidadão de somente ser julgado perante autoridade, prévia e legalmente constituída. O texto da Constituição italiana de 22 de dezembro de 1947, em seu art. 25 dispõe:

Articolo. 25 da Constituição italiana. Nessuno può essere privato del giudice naturale designato per legge. ${ }^{11}$ Nessuno può essere punito, se non per applicazione di una legge che è entrata in vigore prima ha commesso il fatto. ${ }^{12}$ Nessuno può essere soggetto a misure di sicurezza, tranne nei casi previsti dalla legge. ${ }^{13}$

\footnotetext{
${ }^{7}$ A comissão que instituiu a ex-corte dos comissários e cortes da mesma natureza é ilegal e nociva. (tradução livre)

8 Os cidadãos não podem ser subtraídos dos juízes que a lei lhes indicar por nenhuma comissão nem por outras atribuições que as determinadas pelas leis. (tradução livre)

${ }^{9}$ Ninguém poderá ser subtraído do julgamento de seus juízes naturais. (tradução livre)

10 Não se poderá, em conseqüência, criar, comissões ou tribunais extraordinários a qualquer título e sob qualquer denominação que possam ter. (tradução livre)

11 Ninguém pode ser privado do juiz natural designado por lei.

12 Ninguém pode ser punido, senão por aplicação de uma lei que tenha entrado em vigor antes de cometido o facto.

${ }^{13}$ Ninguém pode ser submetido a medidas de segurança, salvo nos casos previstos pela lei.
} 
Deste lado do Atlântico, a constituição dos Estados Unidos da América recebeu duas emendas, e que vêm a corroborar a importância do juiz post factum, assim consignando:

5th amendment. Right of defense and of a judgment by natural judge and according to due process of law, that is, with sufficient legal guarantees. 6th amendment. Right to a speedy and public trial by impartial jury of the State and district in which the crime was committed, with the right to proof of defense and assistance of a lawyer. ${ }^{14}$

Por sua vez, a Declaração Universal dos Direitos do Homem, elaborada em 10 de janeiro de 1948, foi concebida como uma carta de princípios onde se estabelecem e defendem quais os direitos do indivíduo que são inalienáveis, cuja proclamação foi feita pela Assembleia Geral da Organização das Nações Unidas. Este documento político e jurídico traz em seu âmago a repulsa pelas atrocidades cometidas durante o segundo conflito bélico mundial, realçando a importância em seu art. 10 sobre o princípio do juiz natural, quando estabelece: "Everyone is entitles in full equality to a fair and public hearing by on independent and impartial tribunal, in determination of any criminal charge against him."15

Pela Convenção americana sobre Direitos Humanos, assinada na Conferência Especializada Interamericana sobre Direitos Humanos de San José, Costa Rica, em 22 de novembro de 1969, que passou a integrar o sistema jurídico brasileiro no ano de 1992, em virtude da promulgação do Decreto №. 678/1992, quando em seu art. 8.1. estabelece a garantia do juiz natural, constituído antes do fato pelo qual será competente para julgar.

Artículo 8. Garantías judiciales. 1. Toda persona tiene derecho a ser oída, con las debidas garantías y dentro de un plazo razonable, por un juez o tribunal competente, independiente e imparcial, establecido anteriormente

14 Emenda 5a . Direito de defesa e de um julgamento por juiz natural e de acordo com o devido processo legal, isto é, com garantias legais suficientes. (tradução livre) Emenda 6 ${ }^{a}$. Direito a julgamento público e rápido por júri imparcial do Estado e distrito em que o crime tenha sido cometido, com direito a prova de defesa e assistência de um advogado. (tradução livre)

15 "Todos têm direito, em condições de plena igualdade, de ser ouvida publicamente e com justiça por um tribunal independente e imparcial para a determinação de seus direitos e obrigações ou para o exame de qualquer acusação contra ela em matéria penal". (tradução livre) 
por ley, en el escrutado de cualquier acusación penal formulada contra ella, o para que se determinen sus derechos o obligaciones de naturaleza civil, laboral, fiscal o de cualquier otra naturaliza. ${ }^{16}$

Ao integrar o ordenamento jurídico brasileiro, o princípio do juiz natural foi recebido na Constituição Política do Império do Brasil, de 25 de março de 1824, em seu art. 179, inc. VII, que assim asseverava:

Art. 179. A inviolabilidade dos Direitos Civis, e Politicos dos Cidadãos Brazileiros, que tem por base a liberdade, a segurança individual, e a propriedade, é garantida pela Constituição do Imperio, pela maneira seguinte. [...] XVII, à exceção das causas que por sua natureza pertencem a juízos particulares, na conformidade das leis, não haverá foro privilegiado, nem comissões especiais, nas causas cíveis ou criminais.

A primeira Constituição da República dos Estados Unidos do Brasil, promulgada em 24 de fevereiro de 1891, manteve a garantia do juiz natural, não deixando qualquer possibilidade à adoção de tribunais ou juízos de exceção, assim dispondo em seu art. 72, § 23.

Art. 72. A Constituição assegura a brazileiros e a estrangeiros residentes no paiz a inviolabilidade dos direitos concernentes á liberdade, á segurança individual e à propriedade nos termos seguintes: [...] $\S 23$. A excepção das causas, que, por sua natureza, pertencem a juizos especiaes, não haverá fôro privilegiado.

Mais clara e específica no que concerne à vedação para criação ou adoção de juízos de exceção, ou violadores do juiz natural, foi a Constituição da República dos Estados Unidos do Brasil, de 16 de julho de 1934, quando em seu art. 113, número 5, previu:

Art 113. A Constituição assegura a brasileiros e a estrangeiros residentes no paiz a inviolabilidade dos direitos concernentes à liberdade, à subsistencia, à segurança individual e à propriedade, nos termos seguintes:

\footnotetext{
16 "Artigo 8. Garantias judiciais 1. Toda pessoa tem direito a ser ouvida, com as devidas garantias e dentro de um prazo razoável, por um juiz ou tribunal competente, independente e imparcial, estabelecido anteriormente por lei, na apuração de qualquer acusação penal formulada contra ela, ou para que se determinem seus direitos ou obrigações de natureza civil, trabalhista, fiscal ou de qualquer outra natureza". (tradução livre)
} 
[...] 25) Não haverá fôro privilegiado nem tribunaes de excepção; admittemse, porém, juizos especiaes em razão da natureza das causas.

A Constituição dos Estados Unidos do Brasil, de 10 de novembro de 1937, no tópico Dos direitos e garantias individuais, em seu art. 122, não cuidou do princípio do juiz natural, consoante observa-se da leitura de seus números.

O texto da Constituição dos Estados Unidos do Brasil, de 18 de setembro de 1946, com teor democrático em sua essência, não inovou ao preservar a garantia que impossibilita a criação de tribunais de exceção em seu art. 141, § 26, asseverando que "não haverá foro privilegiado nem juízos e tribunais de exceção".

A Constituição da República Federativa do Brasil de 1967, redigida sob a égide do regime militar, em seu art. $150, \S 15$, ao cuidar do princípio do juiz natural, assim dispôs: "A lei assegurará aos acusados ampla defesa, com os recursos a ela Inerentes. Não haverá foro privilegiado nem Tribunais de exceção". Esta redação foi mantida pela redação dada pela Emenda Constitucional №. 1, de 17 de outubro de 1969: "A lei assegurará aos acusados ampla defesa, com os recursos a ela inerentes. Não haverá fôro privilegiado nem tribunais de exceção".

Finalmente, em termos de norma constitucional, a Constituição da República Federativa do Brasil de 1988, promulgada em 5 de outubro de 1988, em seu art. $5^{\circ}$., incs. XXXVII e LII, assegura de forma expressa o princípio do juiz natural e do princípio do juiz competente, nos termos seguintes:

Art. $5^{\circ}$ Todos são iguais perante a lei, sem distinção de qualquer natureza, garantindo-se aos brasileiros e aos estrangeiros residentes no País a inviolabilidade do direito à vida, à liberdade, à igualdade, à segurança e à propriedade, nos termos seguintes: [...] XXXVII - não haverá juízo ou tribunal de exceção; [...] LIII - ninguém será processado nem sentenciado senão pela autoridade competente; [...].

Por esta Constituição, percebe, claramente, que a mesma assegura o direito e garantia fundamental do princípio do juiz natural, por meio do qual somente poderá ser objeto de julgamento os fatos ocorridos em período anterior a criação do órgão encarregado de apreciá-lo e julgá-la. 
Por se tratar de norma de eficácia plena, e atento ao conteúdo do $\S 1^{1017}$ do art. 5‥, da Constituição República Federativa do Brasil de 1988, tem-se que essa norma definidora dos direitos e garantias fundamentais, é de aplicação é imediata.

\section{OS DIREITOS E GARANTIAS FUNDAMENTAIS: OBSERVAÇÃO NA DEFESA E PRESERVAÇÃO DA LEGALIDADE EM FACE DE POSSÍVEIS PRÁtICAS ABUSIVAS DO ESTADO, A FIM DE ASSEGURAR O PLENO ACESSO À JUSTIÇA}

Os direitos e garantias fundamentais representam os valores mais importantes para assegurar a realização do ser humano enquanto pessoa, assumindo a devida correspondência nas normas jurídicas de maior realce da comunidade em que está inserida.

Dentro de sua aplicabilidade, os direitos fundamentais devem ser observados dentro de um cenário de horizontalidade, ou seja, dentro de uma relação entre iguais, os quais buscam a preservação de seus direitos fundamentais e, ainda, sob uma posição de superioridade da Administração pública e o administrado, concebida esta relação como sendo uma relação vertical.

Destarte, os direitos e garantias fundamentais servem para assegurar os valores mais nobres e essenciais para proteção do ser humano, seja ele exercido em face da própria pessoa ou em relação à Administração Pública, comportando uma plêiade de destinatários ou titulares, assim destacados por Ingo Wolfgang Sarlet (2015, p.215):

\footnotetext{
Em que pese à existência, no Brasil, de considerável doutrina utilizando o termo destinatários (no sentido de destinatário da proteção ou tutela do direito) como sinônima do titular de direitos fundamentais, é preciso enfatizar que a terminologia mais adequada e que em termos gerais, corresponde à tendência dominante no cenário jurídico contemporâneo, é a de titular de direitos fundamentais. Titular do direito, notadamente na
}

17 "Art. $5^{\circ}$. [...] $\S 1^{\circ}$ As normas definidoras dos direitos e garantias fundamentais têm aplicação imediata". 
perspectiva da dimensão subjetiva dos direitos e garantias fundamentais, é quem figura como sujeito ativo da relação jurídico-subjetiva, ao passo que destinatário é a pessoa (física, jurídica ou mesmo ente despersonalizado) em face da qual o titular pode exigir o respeito, proteção ou promoção do seu direito.

A própria essência do Estado em sua criação e manutenção concentra-se na proteção e preservação do administrado, não assistindo razão em sentido contrário na qual o Estado é um fim em si mesmo, sendo o administrado o meio para atingir a preponderância desse Estado e de seus administradores. A pessoa humana é o centro e não o Estado. Este foi criado para pessoa e não o contrário. Ademais, não custa lembrar que se vive, no Brasil, numa República.

A proteção do administrado no que diz respeito aos seus direitos fundamentais espraia-se por todos os segmentos da sociedade brasileira, mas delimita o tema ao cerne do presente trabalho, ao que já foi objeto de ponderação linhas acima, mesmo com a previsão de proteção, inclusive do juiz natural, em todos os textos constitucionais, a força violadora da Administração Pública possui presença indelével no Estado brasileiro. Sem citar casos específicos, cabe destacar a exemplificação contida na doutrina de Sergio Ferraz e Adilson Abreu Dallari (2007, p.21), a qual reflete o pensamento sugerido:

\begin{abstract}
A consequência dessa idiossincrasia do direito administrativo brasileiro é por todos conhecida: a Administração sempre se considerou senhora e dona do processo administrativo, decidindo, a seu talante, quando e como instaurá-lo, seu iter, a dimensão da atividade dos administrados em seu bojo, sua publicidade ou reserva etc. Daí também algumas patologias que os advogados brasileiros por vezes enfrentam, tais como: (a) resistência da Administração em conceder vistas de autos de processo administrativo, apesar da existência de expressas determinações legais a respeito; (b) frequência com que as repartições simplesmente se recusam ao recebimento de petições, obrigando o interessado a recorrer ao judiciário, com invocação de garantias constitucionais (invariavelmente, o Judiciário repele a recusa, conectando o tema ao direito constitucional de petição CF, XXXIV "a".
\end{abstract}

Este comportamento estatal no qual prepondera a "força do Estado" não deve prevalecer, em regra, quando em confronto com o direito e a garantia fundamental. A toda evidência que não é crível que a Administração Pública venha a 
desrespeitar uma garantia do jaez do "juiz natural", da vedação da criação de "tribunais de exceção" ao admitir que comissões de sindicância ou mesmo de Processo Administrativo disciplinar venha a ser constituídas "ad hoc" ou mesmo "post factum".

A crítica que pode ser feita, pelo Administrador Público, encontra-se fundada, ao que se percebe, na própria redação do art. 143 e seu § $3^{\circ 18}$, da Lei federal №. 8.112, de 11 de dezembro de 1990, segundo o qual "a autoridade que tiver ciência é obrigada" promover a apuração. Ademais, neste contexto, a autoridade que determinar a instauração da sindicância ou processo administrativo deve mandar assegurar o conteúdo dos incisos do art. 5‥ do texto constitucional, principalmente no que se refere ao princípio do "juiz natural", que também deve ser observado na via administrativa.

A toda evidência que a não observância de referido princípio constitucional não merece prosperar, uma vez que esse entendimento não coaduna com a melhor interpretação do texto constitucional. A interpretação que melhor se adéqua, aos casos envolvendo a envergadura dos direitos e garantias fundamentais, é aquela que oferta ao texto constitucional a sua máxima efetividade. Ademais, diante do alcance concedido a devida proteção dos direitos fundamentais não seria desmedido, ou mesmo, inapropriado estendê-lo ao processo administrativo disciplinar, assim entendido por Romeu Felipe Bacellar Filho (1998, p.297-300):

A normatividade do princípio do juiz natural informa o processo administrativo (inclusive o disciplinar). Quanto ao programa normativo, os enunciados linguísticos dos incs. XXXVII e LIII do art. 5ำ não são incompatíveis com o processo administrativo disciplinar. A expressão "juízo" como assinalada, comporta o sentido de julgamento que ocorre em sede de processo administrativo disciplinar, onde há um juízo administrativo. A expressão 'tribunal', a seu turno, mesmo entendida em sentido técnico, não

\footnotetext{
18 "Art. 143. A autoridade que tiver ciência de irregularidade no serviço público é obrigada a promover a sua apuração imediata, mediante sindicância ou processo administrativo disciplinar, assegurada ao acusado ampla defesa. [...] § $3^{\circ}$. A apuração de que trata o caput, por solicitação da autoridade a que se refere, poderá ser promovida por autoridade de órgão ou entidade diverso daquele em que tenha ocorrido a irregularidade, mediante competência específica para tal finalidade, delegada em caráter permanente ou temporário pelo Presidente da República, pelos presidentes das Casas do Poder Legislativo e dos Tribunais Federais e pelo Procurador-Geral da República, no âmbito do respectivo Poder, órgão ou entidade, preservadas as competências para o julgamento que se seguir à apuração".
} 


\begin{abstract}
é sinônimo de tribunal judiciário. Prova disto, a previsão constitucional do Tribunal de Contas (art. 71) não integrando o poder judiciário. A expressão 'processado' engloba o processo administrativo disciplinar, tendo em vista a afirmação constitucional expressa do 'processo administrativo' no art. 50, inc. LV. O termo "autoridade competente' põe às claras o sentido amplo dos enunciados informadores do princípio.
\end{abstract}

A proteção aos direitos fundamentais exerce forte influência na elaboração dos textos legislativos, não ficando restrito à sua abrangência as práticas do Poder Executivo. Desta forma, a proteção dos direitos fundamentais e sua aplicação imediata representa um dos baluartes do Estado Democrático de Direito. Neste viés, cabe ressaltar a lição de Luiz Fernando Calil de Freitas (2007, p.41), a qual reflete o pensamento aqui assumido de limitação da Administração Pública e do Poder Legislativo.

A concepção originária dos direitos fundamentais como direitos subjetivos públicos, é dizer, direitos de proteção do cidadão em face do Estado, permite concluir, desde logo, que todos os órgãos estatais estejam a eles vinculados, inclusive o legislador quando produzi direito destinado a regular as relações.

Dessa forma, defende-se a obrigatoriedade de observância do Princípio do julgador (juiz) natural, direito e garantia fundamental, como forma de acesso à justiça ${ }^{19}$, na proteção dos direitos do servidor administrado na sindicância e,

\footnotetext{
19 Vale-se, aqui, dos seguintes ensinamentos sobre o acesso à justiça, que entende também devem ser aplicados no âmbito do processo administrativo: "Acesso à justiça não se identifica com a mera admissão ao processo ou possibilidade de ingresso em juízo. Para que haja a efetiva institucionalização do acesso à justiça é indispensável que o maior número possível de pessoas seja admitido a demandar e a defender-se adequadamente (inclusive em processo criminal), segundo também condenáveis as restrições quanto a determinadas causas (pequeno valor, interesses difusos); mas para integralidade do acesso à justiça é preciso isso e muito mais. A ordem jurídicapositiva (Constituição e leis ordinárias) e o lavor dos processualistas modernos têm posto em destaque uma série de princípios e garantias que, somados e interpretados harmoniosamente, constituem o traçado do caminho que conduz as partes à ordem jurídica justa. O acesso à justiça é, pois, a ideia central a que converge toda a oferta constitucional e legal desses princípios e garantias. Assim, (a) oferece-se a mais ampla admissão de pessoas e causas ao processo (universalidade da jurisdição), depois (b) garante-se a todos elas (no cível e no criminal) a observância das regras que consubstanciam o devido processo legal, para que (c) possam participar intensamente da formação do convencimento do juiz que irá julgar a causa (princípio do contraditório), podendo exigir dele (d) a efetividade de uma participação em diálogo - tudo isso com vista a preparar uma solução que seja justa e capaz de eliminar todo resíduo de insatisfação. Eis a dinâmica dos princípios e garantias do
} 
também, no processo administrativo, com o objetivo de evitar os abusos e ilegalidade da autoridade administrativa, principalmente quando se vislumbra as chamadas "comissões de encomenda", não só quando há previsão legal, mas em todo e qualquer caso, a despeito de posição do Supremo Tribunal Federal (STF) ${ }^{20}$.

Aliás, o Superior Tribunal de Justiça (STJ), por intermédio da Primeira Seção, em sede de Mandado de Segurança, a esse respeito, valendo-se do entendimento do Supremo Tribunal Federal (STF), por unanimidade de votos, já decidiu que "É pacífico no âmbito desta Corte que a exigência de comissão permanente para apuração de faltas funcionais só é exigida para os casos determinados em lei, sendo legítima o regramento previsto na Lei n. 8.112/90 para constituição de comissão de processo administrativo disciplinar. Não violação do princípio do juiz natural (STF-MS 27.700 ED, 1a․ T., Rel. Min. Luiz Fux, DJe 28.09.2015)"21_22

Este mesmo Superior Tribunal de Justiça (STJ), na esteira deste posicionamento, apesar do voto divergente, já decidiu:

[...] 1. Pretendem os impetrantes, Policiais Rodoviários Federais, a concessão da segurança para anular o PAD 08.672.002015/2008-77, desde da designação da Comissão Processante, ao fundamento de que a designação de comissão temporária após a ocorrência da infração funcional

processo, em sua interação teleológica apontada para a pacificação com justiça [...]". (ARAÚJO CINTRA, et. al., 2014, 52).

20 “[...] O princípio do juiz natural não resta afrontado, porquanto a comissão a ser designada, e não sorteada, não julgará o mérito - ou melhor, a conduta constante no PAD -, mas, tão somente, conduzirá os atos processuais até a completa instrução do feito". MS 27700 ED/DF - Distrito Federal Emb. Decl. em Mandado de Segurança, relator Min. Luiz Fux, julgamento 08/09/2015, órgão julgador Primeira Turma, publicação Acórdão Eletrônico DJe-193, divulg. 25-09-2015, public. 2809-2015, v. m.

${ }^{21}$ MS 16927/DF MANDADO DE SEGURANÇA 2011/0120824-1, relatora Ministra Regina Helena Costa, órgão julgador S1 - Primeira Seção, data do julgamento 10/05/2017, data da publicação/fonte DJe 15/05/2017.

22 No mesmo sentido: "1. Esta Corte consolidou a orientação e que havendo expressa previsão legal na lei que institui o Estatuto dos Policiais Federais acerca da necessidade de os Processos Administrativos Disciplinares serem conduzidos por uma comissão permanente, não há falar em aplicação subsidiária da Lei $8.112 / 90$ como fundamento para autorizar a constituição de uma comissão processante temporária. Precedentes: REsp. 1.185.375/RJ, Rel. Min. CASTRO MEIRA, DJe 4.4.2011; MS 13.821/DF, Rel. Min. ARNALDO ESTEVES LIMA, DJe 9.4.2010; AgRg no MS 14.310/DF, Rel. Min. OG FERNANDES, DJe 24.9.2009; MS 13.250/DF, Rel. Min. FELIX FISCHER, DJe 2.2.2009". (AgInt. no REsp. 1611614/DF, Agravo Interno no Recurso Especial 2012/0118218-4, relator Ministro Napoleão Nunes Maia Filho, órgão julgador T1 - Primeira Turma data do julgamento 21/02/2017, data da publicação/fonte Je 23/03/2017, v. u.). 
violaria os princípios da legalidade e do juízo natural e a norma contida no art. 53, $\S 1^{\circ}$, da Lei $4.878 / 1965$. 2. É dominante o entendimento no âmbito dessa Corte Superior no sentido que a Lei 4.878/1965, que dispõe sobre as peculiaridades do regime jurídico dos funcionários públicos civil da União e do Distrito Federal, ocupantes de cargos de atividade policial, não se aplica aos Policiais Rodoviários Federais, os quais se sujeitam às disposições da Lei 8.112/1990. 3. Precedentes: MS 19.046/DF, Rel. Ministro BENEDITO GONÇALVES, PRIMEIRA SEÇÃO, julgado em 09/12/2015, DJe 15/12/2015; MS 21.160/DF, Rel. Ministro OG FERNANDES, PRIMEIRA SEÇÃO, julgado em 24/06/2015, DJe 01/07/2015; MS 16.130/DF, Rel. Ministro BENEDITO GONÇALVES, PRIMEIRA SEÇÃO, julgado em 12/11/2014, DJe 10/02/2016; MS 19.750/DF, Rel. Ministro MAURO CAMPBELL MARQUES, PRIMEIRA SEÇÃO, julgado em 14/08/2014, DJe 18/08/2014; MS 19.290/DF, Rel. Ministra ELIANA CALMON, PRIMEIRA SEÇÃO, julgado em 14/08/2013, DJe 23/08/2013; MS18.090/DF, Rel. Ministro HUMBERTO MARTINS, PRIMEIRA SEÇÃO, julgado em 08/05/2013, DJe 21/05/2013; MS 14.827/DF, Rel. Ministro MARCO AURÉLIO BELLIZZE, TERCEIRA SEÇÃO, julgado m 24/10/2012, DJe 09/11/2012; MS 14.848/DF, Rel. Ministro OG FERNANDES, TERCEIRA SEÇÃO, julgado em 14/09/2011, DJe 29/09/2011. 4. A $1^{\text {a }}$ Turma do Supremo Tribunal Federal, no julgamento do AgRg no RMS 27.668/DF, da relatoria do Min. Luis Roberto Barroso, julg. Em 23/02/2016, Dje 11/03/2016, já decidiu que "a Lei no 8.112/1990 não prevê a necessidade de comissão permanente para apurar supostas infrações disciplinares praticadas por servidor público federal". 5. "A designação de comissão disciplinar posteriormente ao fato, por si só, não configura violação do princípio do juiz natural, pois à autoridade se impõe a apuração somente a partir da ciência de irregularidade, conforme o art. 143 da Lei $n^{\circ}$.112/90" (RMS 31207/DF, Relator(a): Min. DIAS TOFFOLI, Primeira Turma, julgado em 18/12/2012, Processo Eletrônico DJe-036 divulg. 22-02-2013 public. 25-02-2013). 6. "O princípio do juiz natural não resta afrontado, porquanto a comissão ser designada, e não sorteada, não julgará o mérito - ou melhor, a conduta constante no PAD -, mas, tão somente, conduzirá os atos processuais até a completa instrução do feito (MS 27700 ED, Relator(a): Min. LUIZ FUX, Primeira Turma, julgado em 08/09/2015, Acórdão Eletrônico DJe-193 DIVULG 25-09-2015 PUBLIC 28-09-2015). [...]. [MS 15924/DF Mandado de Segurança 2010/0213029-2, relator Ministro Napoleão Nunes Maia Filho, relator(a) p/ Acórdão Ministro Mauro Campbell Marques, órgão julgador S1 Primeira Seção, data do julgamento 28/09/2016, data da publicação/fonte DJe 02/02/2017, v. m.].

\section{Apesar desta decisão, o voto divergente, assim declarou em seu voto:}

VOTO VENCIDO, Min. Napoleão Nunes Maia Filho "[...] não se pode aceitar, em processo administrativo sancionador e judicialiforme, que é o PAD, que alguém seja punido por decisão gerada em comissão ad hoc, formada para apurar fatos pretéritos, pois tal importa em infringir acintosamente a garantia mais básica do justo processo jurídico, qual seja, a de que a constituição do órgão estatal sancionador seja precedente à ocorrência dos fatos, nisso se envolvendo a própria garantia do juiz natural". "O fato de não haver uma lei assegurando tal garantia, não impede que se aplique o preceito prevê assegura o direito ao devido processo legal (art. $5^{\circ}$., LIV) e ao juiz natural (art. 50., XXXVII e LIII). O princípio do juiz natural 


\begin{abstract}
também há que ser respeitado na esfera administrativa, quando nela se realiza processo administrativo disciplinar; aí reside a importância da Comissão Disciplinar permanente, constituída antes dos fatos que se pretende apurar, de modo a evitar a escolha direcionada dos seus membros e, até mesmo, eventuais resulta evitar a escolha direcionada dos seus membros e, até mesmo, eventuais resultados encomendados, o que deve ser evitado com veemência.
\end{abstract}

Desta forma, acredita que não é o fato de não estar prevista, na lei, a exigência de que a comissão de sindicância ou do processo administrativo seja nomeada antes da ocorrência do fato faltoso (juiz natural), sob o acicate que a mesma somente conduzirá os atos processuais até a completa instrução do feito, que não se observará o princípio do juiz natural.

Embora a comissão de sindicância ou do processo administrativo não profere um julgamento sobre o mérito da questão posta sob sua condução, mas somente proceder a instrução, note-se que estes atos processuais poderão ser conduzidos de uma forma a incriminar o servidor administrado.

Observe-se que uma das fases da sindicância ou do processo administrativo, que é justamente a fase de instrução, fica a cargo da comissão, devendo, esta, inclusive, observar o contraditório e a ampla defesa quando desta fase de instrução. Não é demais lembrar que estes atos de instrução têm conteúdo tipicamente jurisdicional, ainda mais quando a autoridade utiliza-se de toda a prova produzida, que serve, normalmente, para embasar a decisão, seguindo, na esmagadora maioria dos casos, a orientação da comissão constante do relatório final.

Com efeito, acredita que deve prevalecer, nesses casos de sindicância e de processo administrativo, o princípio da segurança jurídica, o princípio do devido processo legal, o princípio da legalidade, princípio da moralidade e princípio da impessoalidade ${ }^{23}$ e, sobretudo, o princípio do juiz natural. Daí a necessidade de criação, constituição de comissões permanentes, com nomeação dos seus integrantes antes da ocorrência dos fatos a serem apurados, no que se refere a falta funcionais.

${ }^{23}$ Vide, novamente, nota de rodapé 1. 
O próprio Superior Tribunal de Justiça (STJ), em decisões judiciais também já teve oportunidade de decidir pela exigência do juiz natural, ainda que a exigência não se encontre não prevista em leis administrativas. Assim, já decidiu o referido órgão jurisdicional:

[...] Tenho defendido que ainda que a Lei 4.878/1965 não se aplique aos integrantes da Polícia Rodoviária Federal, é possível a aplicação do preceito garantista que exige a instrução do procedimento administrativo disciplinar no âmbito de uma comissão permanente, reconhecendo a necessidade da previalidade da Comissão Processante, ou seja, a sua constituição antes dos fatos sancionáveis, o que, aliás, guarda estrita harmonia com as exigências substantivas do justo processo jurídico, expressamente albergado na Carta Magna. [...] Não se pode aceitar, em processo administrativo sancionador e judicialiforme, como é o caso do PAD, que alguém seja punido por decisão gerada em comissão ad hoc, formada para apurar fatos pretéritos, pois tal importa em infringir acintosamente a garantia mais básica do justo processo jurídico, qual seja, a de que a constituição do órgão estatal sancionador seja precedente à ocorrência dos fatos, nisso se envolvendo a própria garantia do juiz natural, um dos pilares de ferro do due process of Law, tão encomiado pelos juristas em seus trabalhos doutrinários. [...] Ocorre que esta Corte fixou a orientação de que os Policiais Rodoviários Federais se sujeitam às disposições da Lei $8.112 / 1990$, que nada dispõe sobre necessidade de ser permanente a Comissão que conduz o Processo Administrativo Disciplinar instaurado para apurar responsabilidade de Servidor por infração praticada no exercício de suas atribuições, não havendo que se falar em nulidade por incompetência da Comissão Processante. Precedentes: MS 21.160/DF, Rel. Min. OG FERNANDES, DJe 1.7.2015; MS 19.750/DF, Rel. Min. MAURO CAMPBELL MARQUES, DJe 18.8.2014; MS 18.090/DF, Rel. Min. HUMBERTO MARTINS, DJe 21.5.2013; MS 19.290/DF, Rel. Min. ELIANA CALMON, DJe 23.8.2013 e MS 14.827/DF, Rel. Min. MARCO AURÉLIO BELLIZZE, DJe 9.11.2012. [...]"24.

\section{NECESSIDADE E OBRIGATORIEDADE DE NOMEAÇÃO PERMANENTE E PRÉVIA DA COMISSÃO SINDICANTE E DO PROCESSO ADMINISTRATIVO DISCIPLINAR}

Como já afirmado antes, no tópico anterior, apesar da cizânia das decisões dos Tribunais Superiores, Supremo Tribunal Federal (STF) e Superior Tribunal de

24 MS 19045/DF Mandado de Segurança 2012/0171625-0, relator Ministro Napoleão Nunes Maia Filho, órgão julgador S1 - Primeira Seção, data do julgamento 23/11/2016, data da publicação/fonte DJe 01/12/2016, v. u. 
Justiça (STJ), é importante ressaltar o fato de que o constituinte originário não fez qualquer distinção quanto à matéria passível de julgamento, ou mesmo sobre a segregação da competência administrativa ou judicial, razão pela qual, entende-se, é incontroverso que a vedação de criação de tribunais de exceção está incluída, por igual, as matérias administrativas.

Como consequência, é possível conceituar o juiz natural como sendo aquele que é criado em momento anterior a prática do fato faltoso a ser julgado. Gilmar Ferreira Mendes (2013, p.377), sobre o tema, assim se manifesta:

\begin{abstract}
Dessa forma, pode-se definir o princípio do juiz natural como expressão do princípio da isonomia e também um pressuposto da imparcialidade. Nasce vinculado ao pensamento iluminista e, consequentemente, a Revolução Francesa, com a qual foram suprimidas as justiças senhoriais, e todos passaram a ser submetidos aos mesmos tribunais. A primeira de suas leis processuais, em 11.08.1789, foi expressamente para vetar qualquer manipulação nesse sentido (extinguindo a justiça senhorial), consolidandose o princípio do juiz natural da Constituição de 1791 e na legislação subsequente. Vem a lume, assim, com o escopo de extinguir os privilégios das justiças senhoriais (foro privilegiado), assim como afastar a criação de tribunais de exceção, ditos ad hoc ou posfactum. Destarte, todos passam a ser julgados pelo "seu" juiz, o qual se encontra com sua competência previamente estabelecida pela lei, ou seja, em uma lei vigente antes da prática do crime.
\end{abstract}

Não se pode ter, diante desta fundamentação constitucional, no sistema jurídico processual brasileiro, a criação de órgãos julgadores post factum, entendendo-se estes como aqueles nomeados, criados, para realizar o julgamento de questões controvertidas em relação aos fatos anteriores da nomeação da comissão. É a posição de Nelson Nery Junior (2016, p.165):

O princípio do juiz natural se aplica, igualmente, no processo administrativo. Fala-se, aqui, em princípio do julgador natural, dimensão do princípio constitucional do juiz natural no direito administrativo. Qualquer que seja a matéria submetida ao julgador administrativo, este deverá ter sido préconstituído na forma da lei e ser imparcial para o julgamento. Esse preceito vale tanto para o processo administrativo disciplinar como também para os demais processos administrativos (v. g. processo sancionador de imposição de sanções administrativas aos administrados, processos de licitação etc.). 
Ao argumento de que na Administração Pública prepondera o princípio da legalidade, presente no art. $5^{\circ}$., inc. $\|^{25}$, combinado com 0 art. 37, caput, da Constituição da República Federativa do Brasil de 1988, como garantia bifronte para ser usada pela pessoa frente à atuação do Estado fazendo ou deixando de fazer alguma coisa, bem como para proteção contra o agir abusivo do agente estatal lato sensu, ou seja, "a legalidade representa uma das maiores garantias dos cidadãos, que não poderão ser obrigados a fazer ou ser coagidos a deixar de fazer alguma coisa, senão em virtude de lei. Essa exigência vale tanto para os particulares como para o Estado" (NOHARA, 2015, p.67).

Desta forma, em termos comparativos, se dentro do processo licitatório, disciplinado legalmente na Lei federal ํo. 8.666/93, de 21 de junho de 1993, bem como na própria inovação produzida na legislação que regula as compras realizadas pelo Poder Público prevista, instituída pelo pregão presente na Lei federal №. 10.520 , de 17 de julho de 2002. ${ }^{26}$, em questões patrimoniais, com maior razão que no processo administrativo disciplinar, onde é a pessoa que está sujeita a uma sanção administrativa, maior é o dever da presença de uma comissão nomeada a cada ano, com o escopo de evitar que eventual comissão seja "escolhida" com interesses escusos ou não. Retorna-se, novamente, a lição de Nelson Nery Junior (2016, p.165):

\begin{abstract}
Não é raro ver-se na administração pública ofensa ao princípio constitucional do julgador natural com a formação de comissões sindicantes ou processante constituídas ex post facto, caracterizando indiscutivelmente juízo de exceção. Essas comissões, nomeadas depois da ocorrência do fato, tanto podem ter sido formada para proteger o sindicado ou processado como para prejudicá-lo, pois a autoridade nomeante pôde escolher o acusador e/ou julgador administrativo já tendo conhecimento do fato e/ou de quem foi seu autor. O correto é nomear-se comissão sindicante ou
\end{abstract}

\footnotetext{
25 "Art. $5^{\circ}$. Todos são iguais perante a lei, sem distinção de qualquer natureza, garantindo-se aos brasileiros e aos estrangeiros residentes no País a inviolabilidade do direito à vida, à liberdade, à igualdade, à segurança e à propriedade, nos termos seguintes: [...] II - ninguém será obrigado a fazer ou deixar de fazer alguma coisa senão em virtude de lei; [...]".

26 "Art. $3^{\circ}$. A fase preparatória do pregão observará o seguinte: [...] IV - a autoridade competente designará, dentre os servidores do órgão ou entidade promotora da licitação, o pregoeiro e respectiva equipe de apoio, cuja atribuição inclui, dentre outras, o recebimento das propostas e lances, a análise de sua aceitabilidade e sua classificação, bem como a habilitação e a adjudicação do objeto do certame ao licitante vencedor".
} 
processante previamente, por exemplo, para atuar no decorre do ano seguinte ao da nomeação. Aí, sim, haverá respeito ao princípio constitucional do acusador e do julgador natural, pois foram préconstituídos. O réu desse processo administrativo já saberá quem são seu acusador e seu juiz natural.

Sobreleva enfatizar a Instrução que consta do site da Controladoria Geral da União, que consagra regra violadora dos direitos e garantias fundamentais aqui defendidas, pelo fato de que a orientação prescrita vem a consagrar a "criação pontual" para o caso, não prevendo a pré-constituição da comissão sindicante ou processante, nos seguintes termos:

Como se dá a instauração de um procedimento disciplinar? A instauração de qualquer procedimento disciplinar se dá, pontualmente, com a necessária publicação de ato instaurador ou portaria inaugural no boletim de serviço (ou no boletim de pessoal) do órgão responsável por publicação interna na jurisdição da unidade instauradora ou no Diário Oficial. ${ }^{27}$

O que vem a causar certa perplexidade encontra-se destacado no julgado proferido pelo Supremo Tribunal Federal (STF), na decisão presente no RMS 31.207, relator Ministro. Dias Toffoli, Primeira Turma, DJe 25/2/2013, que decidiu pela ausência de violação ao juiz natural à indicação dos integrantes da comissão processante ter ocorrido após à infração:

[...] 2. A designação de comissão disciplinar posteriormente ao fato, por si só, não configura violação do princípio do juiz natural, pois à autoridade se impõe a apuração somente a partir da ciência de irregularidade, conforme o art. 143 da Lei no ${ }^{8} .112 / 90$. Não se faz evidente nos autos eletrônicos qualquer prejuízo à defesa do recorrente que imponha o reconhecimento da nulidade por afronta ao disposto no $\S 2^{\circ}$ do art. 53 da Lei nำ 4.878/65.

Todavia, os comandos contidos na decisão acima transcrita devem ser aferidos cum grano salis, pela própria fundamentação subsequente, a qual destaca a superficialidade da argumentação feita pelo impetrante, razão pela qual a decisão do pretório excelso deve ser vista com as devidas reservas.

$27 \quad$ http://www.cgu.gov.br/sobre/perguntas-frequentes/atividade-disciplinar/fases-do-procedimentodisciplinar-instauracao\#1, acesso em 24 de jul. 2018. 
Verifico que o recorrente não indicou qualquer indício de que o artigo 149 da Lei no 8.112/1990 teria sido violado, pois a norma, apenas, prevê que a comissão será integrada por servidores estáveis e o presidente deve "possuir cargo efetivo superior ou de mesmo nível, ou ter nível de escolaridade igual ou superior ao do indiciado.

Desta forma, não se deve, de forma precipitada, assumir o entendimento peremptório de que o Supremo Tribunal Federal (STF) vem manifestando, em julgamento favorável a designação de comissão sindicante ou de composição do Processo Administrativo Disciplinar (PAD) "ad hoc", ou posterior ao fato a ser apurado.

De acordo com o entendimento do Conselho Nacional de Justiça (CNJ), nos autos de Processo Administrativo Disciplinar n‥ 200910000019225, relator Conselheiro Ives Gandra, consubstanciado em acórdão, nos termos da ementa abaixo transcrita, cabe ressaltar os seus pedagógicos comandos, assim descritos:

Na realidade, o princípio do juiz natural reveste-se, em sua projeção políticojurídica, de dupla função instrumental, pois, enquanto garantia indisponível, tem, por titular, qualquer pessoa exposta, em procedimento judicial ou administrativo-disciplinar, à ação persecutória do Estado, e, enquanto limitação insuperável, incide sobre os órgãos do poder incumbidos de promover, judicial ou administrativamente, a repressão penal ou, quando for o caso, a responsabilização disciplinar. Vê-se, desse modo, que o postulado da naturalidade do juízo, ao qualificar-se como prerrogativa individual ("ex parte subjecti"), tem, por destinatário específico, o réu, ou, quando for o caso, o sindicado/indiciado, erigindo-se, em consequência, como direito público subjetivo inteiramente oponível ao próprio Estado. Esse mesmo princípio, contudo, se analisado em perspectiva diversa, "ex parte principis", atua como fator de inquestionável restrição ao poder de persecução penal ou disciplinar, submetendo, o Estado, a múltiplas limitações inibitórias de suas prerrogativas institucionais. Isso significa que o postulado do juiz natural deriva de cláusula constitucional tipicamente bifronte, pois, dirigindose a dois destinatários distintos, ora representa um direito do réu ou do indiciado/sindicado (eficácia positiva da garantia constitucional), ora traduz uma imposição ao Estado (eficácia negativa dessa mesma garantia constitucional). O princípio da naturalidade do juízo, portanto, encerrando uma garantia constitucional, limita, de um lado, os poderes do Estado (impossibilitado, assim, de instituir juízos "ad hoc" ou de criar tribunais de exceção) e assegura, ao acusado (ou ao sindicado/indiciado), de outro, o direito ao processo (judicial ou administrativo) perante autoridade competente, abstratamente designada na forma de lei anterior (vedados, em conseqüência, os juízos "ex post facto"). 
Percebe-se, apesar de divergências, mormente em decisões judiciais, a necessidade da obrigatoriedade do princípio do juiz natural (julgador natural), não só em processos judiciais, mas, também, nas sindicâncias e nos processos administrativos que visam apurar responsabilidade administrativa, passível de aplicação de sanção administrativa (repreensão, suspensão, demissão).

\section{CONCLUSÃO}

A Constituição da República Federativa do Brasil de 1988, no art. 5., inc. XXXVII, afirma que não haverá juízo ou tribunal de exceção. Em virtude desta norma, a contrário sensu, decorre o princípio do juiz natural. Muitos estudiosos do Direito entendem que esTa norma só se aplica no processo judicial. No entanto, defende-se, no presente texto, que o referido princípio coexiste no processo administrativo e deve ser observado obrigatoriamente também na sindicância e no processo administrativo disciplinar, devendo, então, a comissão que desenvolverá toda atividade processual, principalmente a fase de instrução, ser constituída antes da ocorrência fatos apontados como infrações disciplinares e sujeitos a sanção administrativa.

Conclui-se, que não pode haver as comissões temporárias ad hoc, constituídas após os fatos faltos, devendo haver as comissões permanentes, constituídas na Administração Pública, sempre da ocorrência dos fatos disciplinares faltosos. As comissões temporárias, ad hoc, normalmente são verdadeiras "comissões de encomenda", prejudicando os direitos e garantias fundamentais e, também, os princípios da Administração Pública, ou seja, o princípio da legalidade, princípio da moralidade, princípio da eficiência e princípio da impessoalidade, além de outros princípios, como o princípio do devido processual legal e princípio da segurança jurídica. Sem a observância desses princípios, conclui que não se pode falar em acesso à justiça de forma plena, útil e eficiente, com justiça nas decisões. 


\section{REFERÊNCIAS}

ARAÚJo CINTRA, Antonio Carlos de, GRINOVER, Ada Pellegrini, DINAMARCO, Cândido Rangel. Teoria geral do processo. 30 ed., São Paulo: Malheiros, 2014.

BACELLAR FILHO, Romeu Felipe. Princípios constitucionais do processo administrativo disciplinar. São Paulo : Max Limonad, 1998.

CGU - Controladoria Geral da União. Disponível em: $<$ http://www.cgu.gov.br/sobre/perguntas-frequentes/atividade-disciplinar/fases-doprocedimento-disciplinar-instauracao\#1>. Acesso em: 4 fev. 2019.

FERRAZ, Sérgio; DALLARI, Adilson Abreu. Processo Administrativo. São Paulo : Malheiros, 2007.

FREITAS, Luiz Fernando Calil de. Direitos fundamentais: limites e restrições. Porto Alegre : Livraria do Advogado, 2007.

MEDINA, Paulo Roberto de Gouvêa. Teoria Geral do Processo. 4 ed. rev., atual. e ampl. Salvador: Juspodivm, 2018, p. 45/46.

SARLET, Ingo Wolfgang. A eficácia dos direitos fundamentais: uma teoria Gerald os direitos fundamentais na perspectiva constitucional. Porto Alegre: Livraria do Advogado, 2015.

STRECK, Lenio L., SARLETT, Ingo W., (coords) Comentários À Constituição. São Paulo : Saraiva/Almedina, 2013.

MENDES, Gilmar Ferreira. Comentário ao art. 5, XXXVII In: CANOTILHO, J.J. Gomes.

NERY JUNIOR, Nelson. Princípios do processo na Constituição Federal: (processo civil, penal e administrativo). São Paulo : Revista dos tribunais, 2016, p. 165.

NOHARA. Irene Patrícia. Direito administrativo. São Paulo ; Atlas, 2015, p. 67. 